\title{
Political Corruption: Harm to State Foundations and Public Interests
}

\author{
Endoltseva Alla V. ${ }^{1,2}$, Platonova Natalya I. ${ }^{1}$ \& Endoltseva Yulia V. ${ }^{3}$ \\ ${ }^{1}$ Department of Legal Foundations of Management, Moscow State Institute of International Relations, Russia \\ ${ }^{2}$ Department of Criminal Procedure, Moscow University of the Ministry of Internal Affairs of Russia named \\ after V.Ya. Kikot, Leading Researcher of Research Institute of the Federal Penitentiary Service of Russia, Russia \\ ${ }^{3}$ Department of Criminal Procedure, Moscow University of the Ministry of Internal Affairs of Russia named \\ after V.Ya. Kikot, Russia \\ Correspondence: Platonova Natalya I., Department of Legal Foundations of Management, Moscow State \\ Institute of International Relations, Russia. E-mail: platonovani@gmail.com
}

Received: May 29, $2019 \quad$ Accepted: July 7, $2019 \quad$ Online Published: July 10, 2019

doi:10.5539/jpl.v12n3p18 URL: https://doi.org/10.5539/jpl.v12n3p18

\begin{abstract}
The problem of political corruption is quite acute for all countries. Often, methods to counter this phenomenon are not effective. Sometimes, this happens because of the specifics of political corruption: it is practically legitimate in the view of citizens. Society perceives it as a "necessary" element of the political struggle. At the same time, it undermines the democratic the basic foundations of the state, leads to the fact that constitutional rights of citizens become only declarative. This is even more dangerous as only few subject categories are involved in corruption offenses, thus it is "latent" and not obvious to most citizens.

In this regard, it is necessary to make a complex comprehensive analysis of the types of manifestations of political corruption, determine their essence and identify corruption risks.
\end{abstract}

Keywords: political corruption, electoral corruption, political financing, favoritism, nepotism, transparency

\section{Introduction}

Corruption has been known in all periods of peoples' evolution and in all socio-political formations. The issue of spreading and counteraction of criminality acquired not only national, but also global significance in the 2000s. Society is now aware of real danger corruption causes. It is already known that manifestations of corruption are found both in totalitarian and democratic states, both in economically and politically underdeveloped countries, and even in superpowers. Today we can say that corruption is global.

Many well-known Western researchers paid increased attention studying corruption. It is interesting to note that many approaches have not lost their relevance today. Niccolò Machiavelli, who compared corruption with phthisis, saying that it is difficult to recognize, but it is still easier to treat immediately, otherwise it is extremely difficult to cure $^{1}$ is a good example.

The complexity of countering corruption is justified with the fact that corruption relations are not homogeneous. In other words, they arise and exist in various spheres of each state society's life, their subjects are various, the goals are also very distinguish. It is possible to classify corruption activities by the spheres of manifestation: economic, administrative and managerial, social, political corruption. Today, there is a world tendency to politicize corrupt relations. This is an exact object of this research paper.

Political corruption is a corruptive or corruption-related form of political struggle of the ruling or opposition elites, parties, groups, corporations or individuals for power, has an active relationship with the corruption of the civil servants. This type of corruption can not only destroy fundamental democratic processes ${ }^{2}$, but also undermine constitutional and legal foundations of state power, as well as its authority inside the country and internationally.

\footnotetext{
${ }^{1}$ Machiavelli, N. (1954). Opere. Milano - Naples.

${ }^{2}$ Ippolitov, K.H., Makarov, V.B., (2008). Poniatie i istochnik korrupcii (Definition and sources of corruption). Sledovatel. № 5. pp. 24-29.
} 
It is worth noting that earlier the purpose of corruption was to obtain material benefits. Today it is not only and not so much the desire to get material gain, as political enrichment, i.e. the conquest and retention of power in order to be able to influence the adoption of certain political decisions.

Political corruption is the most effective form of power struggle. Moreover, it undermines the ability of the state to effectively manage, undermines the foundations of democracy, what sooner or later leads to increasing of public discontent. The fight against this type of corruption is a difficult task. Society perceives it as inherent part of political struggle, as a kind of objectively established phenomenon. Political struggle for power is perceived by people as an ordinary phenomenon assumed by the very nature of a political party ${ }^{3}$, and therefore political corruption often does not cause a negative public reaction to those, who are engaged in political activities. The problem is aggravated with the fact that it is highly latent phenomenon; less number of individuals makes it less obvious to the general public and determines its features.

Another distinctive feature of political corruption is that it is often not materially embodied, and is expressed only in providing support for a particular political group, a political decision, etc. Moreover, there may be a significant time gap between the act and the receipt of an unlawful "benefit". All of the above leads to the difficulty of proving the fact of committing a corruption offense.

\section{Literature Review}

There were several groups of sources at the disposal of researchers studying the problems of political corruption. First of all, the legal documents of the United Nations, the Council of Europe, containing the main directions of countering corruption and, in particular, of political corruption, were of great interest.

Documents of international organizations such as GRECO and Transparency International should be noted especially. For over a decade, GRECO has been conducting research of the laws of member countries to identify corruption risks, develops recommendations for improving anti-corruption legislation, and also conducts research, evaluating the effectiveness of made changes.

The third group of sources consists of national legal acts. The legislation of the countries of the European Union, Serbia, Russia and some other states was analyzed. Exploring certain types of political corruption, an important source was freely available financial reports of political parties, their program documents.

The scientific literature sources for researchers were the works of the following authors: D. Hough. Corruption, Anti-Corruption and Governance (Political Corruption and Governance) (2013), B. Buchan and L. Hill. An Intellectual History of Political Corruption (Political Corruption and Governance) (2014), Johnston, Michael. Political Corruption: Concepts and Contexts (2017), Mark Grossman. Political Corruption in America (2017), N. Ram. Why Scams are Here to Stay: Understanding Political Corruption in India (2017), Matthew M. Carlson and Steven R. Reed Political Corruption and Scandals in Japan (2018). Issues of political financing, electoral corruption were studied in the works of other scholars - Alexander Herbert E. (1976): Financing Politics: Money, Elections and Political Reform, Pilar Del Castillo Vera (1985) La financiación de Partidos y candidatos en las democracias occidentales, Arthur B. Gunlincs (2000): Campaign and Party Finance in North America and Western Europe, Ingrid van Biezen (2003): Financing political parties and election campaigns guidelines, Gaspar Ariño Ortiz (2009): La Financiacion de los Partidos Politico: Foro de la sociedad civil., Mataković Hrvoje (2007) Foreword, in: Novac I politika, Mitin G.N. (2015): Political parties funding, Platonova N.I. (2017): Financing of the current activity of the political parties.

In general, literature analysis shows that despite of the abundance of sources devoted to the fight against corruption in general terms, political corruption as an independent phenomenon, having its own characteristics, was given special attention only in the modern period. The scientific works identified the essence of political corruption, its goals, the subjects of political corruption, the nature of their corruption and so on.

\section{Research Methodology}

Writing this article, the authors used traditional scientific methods: analysis, synthesis, analogy, generalization and comparison, systematic method, comparative legal method, legalistic and formal-logical, etc.

\section{Findings and Discussion}

\subsection{Types of Political Corruption}

Previously, political corruption was identified as electoral corruption, as corruption in the electoral process. This

\footnotetext{
${ }^{3}$ Kwon, D.A., (2015). Politicheskaia korrupciia: poniatie, celi, sub`ekty (Political corruption: concept, goals, subjects). Vlast. № 7. pp. 45-52.
} 
approach is hardly justified at the present stage. Electoral corruption is only a part, one of the types of political corruption, as well as illegal political financing, manifestations of favoritism and corruption in the civil service.

In accordance with the goals of political and corruptive actions, political corruption can be distinguished at the stage of conquest of power (in this case, indeed, this is electoral corruption) and at the stage of retaining power, where corruption is more widespread in terms of the number of acts ${ }^{4}$.

\subsection{Electoral Corruption}

Let us pay tribute to the tradition and consider in more detail corruption offenses in the framework of the electoral process. Electoral corruption is the provision of benefits to certain political parties, political groups, restriction of political competition and unlawful use of resources to distort the results of free will of citizens. In this case, the subjects are political parties, candidates for elected positions and persons interested in obtaining a certain "illegal result" or "lawful result" obtained by unlawful actions. It is worth noting that in this case only electoral activity of political parties is considered, that is, aimed at the realization of its main goal - the struggle for power. The danger of electoral corruption lies in the fact that the absence of an adequate response and ineffective struggle against this type of corruption leads to the deformation of the country's electoral system.

The main risks are established in order of financing election campaigns of parties and individual candidates. There are the features of this type of financing: the strictly targeted nature of the provision and spending of funds, the temporary nature - only during the election campaign, the special procedure for monitoring the implementation of legislation.

Sources of electoral funding, as a rule, are the party's own funds (including cases of nomination of candidates from the party, for example, nomination for the presidency) or individual candidates and donations. Donations are a type of gift contract, its subject is cash and other property. Donations must correspond to two principles: voluntariness and gratuitousness 5 .

For the purpose of counteracting electoral corruption, the legislator provides the creation of a special "electoral" fund to which all funds of parties / candidates are transferred. Attraction and expenditure of funds outside the electoral fund is prohibited. The laws of many states have defined such acts as criminal offenses.

Another type of electoral corruption is the bribing of voters, for example, creating conditions for the voter dependence (material and other) on his electoral behavior. There are criminal liability for falsifying electoral documents (article 142 of the criminal code) or election results (article 142.1), and unlawful issuing and receiving a ballot paper (article 142.2) in Russia.

It is worth noting that, being illegal in its legal nature, not all acts related to electoral corruption are provided as administrative offenses or criminal offenses. An example is the abuse of administrative power resources: the initiation of inspections by regulatory authorities against political opponents. Such inspections are carried out within the framework of the existing legislation, but they pursue other goals, for example, intimidation, obstruction of activity. Another example is the abuse of institutional resources.

Particular political parties or candidates may be provided with belonging to the state (municipality) buildings, premises, etc. on more favorable terms during the election campaign. It is necessary to note the abuse of the information resource - "loyal" political parties / candidates are given airtime on more favorable terms, more than the prescribed amount for free access to the state media.

Thus, the most effective mechanism for countering electoral corruption can be the gradual improvement of legislation in this area on the basis of the transparency principle. The creation of the most transparent, open procedure for holding elections, clear requirements for candidates, election campaigns and, of course, the procedure for attracting and spending financial resources, contributes to minimizing corruption risks. However, such measures are hardly sufficient. It is necessary to provide citizens with access to information, to carry out measures on political and legal education of citizens in order to create an intolerant attitude of society towards corruption in general and political corruption in particular. Electoral corruption can be reduced only when it is not legitimate.

The paradox is that parties, as an institution of civil society and according to the goals of their creation and

\footnotetext{
${ }^{4}$ Kwon, D.A. (2015.) Politicheskaia korrupciia: poniatie, celi, sub`ekty (Political corruption: concept, goals, subjects). Vlast. № 7. pp. 45-52

${ }^{5}$ Mitin, G.N. (2018). Kriterij dobrovol’nosti pozhertvovanij $\mathrm{v}$ konstitucionnom zakonodayel’stve (dlia celej kontrolia finansirovaniia politicheskih partij i izbiratel'nyh kompanij kandidatov i izbiratel'nyh ob'edinenij) (Criteria for voluntary donations in constitutional legislation (for the purpose of controlling the financing of political parties and election campaigns of candidates and electoral associations)). Konstitucionnoe i municipal'noe pravo. No. 8. pp. 46-49.
} 
activity, should be the subject of the state's anti-corruption policy.

\subsection{Illegal Political Financing}

Analyzing this type of political corruption a central place is given to the parties. So, political financing or political investment is the legal or illegal financing of the current activities of political parties. In this case, we are talking about the current activities of the parties. They are created and operate continuously, carrying out ongoing, economic activities, conducting advocacy work, attracting supporters. In modern conditions, the effectiveness of parties is determined by their ability to attract financial resources in the proper amount. In these circumstances, the task of states is to implement the legal regulation of party financing, helping reduce corruption risks to the maximum possible minimum.

The study showed that there are three models of party funding in the world today. The first is characterized by a high proportion of "private funds" in budget formation. As a rule, these are the countries of the Anglo-Saxon legal family. For example, the dominant approach in the UK is that parties are free to attract money and other financial resources without limiting their volume; the second model, on the contrary, reflects the predominance of the role of the state in the party budgets formation (Russia, Spain). The legislator proceeds from the fact that the excessive influence of "private funds" leads to increasing of political corruption and the party independence loss in making political decisions. And finally, the third model is an attempt to preserve a certain balance of two main sources of party funding (with a certain degree of conditionality, Germany can be called).

So, let's dwell on state financing. It is carried out directly - the provision of subsidies, and indirectly - free airtime, tax incentives, exemptions for postage, etc. For example, income received from the state budget, donations are not subject of corporate income tax (Cyprus, Russia, Italy and others), the provision of exemptions for postage (Cyprus, Italy, Spain, Russia), the provision of state-owned buildings / premises for meetings, congresses and other events held by political parties.

There is unanimity in the scientific literature concerning indirect party funding. This kind of party support is necessary because of their special significance for society, for providing equal conditions and opportunities for the development of political competition. On the contrary, controversy regarding direct state funding does not abate. On the one hand, state financing sets itself the task of creating conditions for the existence of a multi-party system as an institution of democracy and a guarantee of political pluralism. Public funds also serve as a mechanism for limiting the excessive influence of private investment on political parties and, in particular, on the political decisions that they make or lobby later. On the other hand, the threat of the nationalization of political parties and the loss of their independence is created. Moreover, such obligations are a burden, because the relevant funds can be spent on more urgent social needs of the country. Let us pay attention to the fact that the procedure for determining the volume of party state financing is established with legislative acts adopted by parliament. Thus, parliamentary parties may pursue private interests, rather than state ones. In this regard, the experience of Germany seems to be interesting, where changes of the size of state subsidies to parties come into effect after the next regular elections to the federal legislature. Each of these arguments is reasonable, but it still seems that direct government funding can be an effective mechanism to counter political corruption, take into account certain conditions. First of all, government funding must comply with the principle of reasonableness, as stated in the PACE Recommendation 1516 (2001) "On financing political parties". In other words, the size of state support should correspond to the required amount of subsidies for parties to achieve their statutory goals, but should not lead to "breaking ties between political parties and its electorate".

There is hardly any formula for determining the amount of public financing that would help to establish a balance between private and public financing. The task of each state is to determine the most optimal amount of public funding. In general, it seems unacceptable cases when government subsidies become the budget-forming source of party funding.

Such a source of party funding as donations is extremely important for the formation of party budgets. A donation is a gift agreement, the subject of which is the transfer of a batch of a certain amount of money or property from individuals and / or legal entities. A feature of the donation is that it has a strictly target character. Donors provide funds for the implementation of the statutory goals and objectives of the parties. Another characteristic feature is a special subject composition of such legal relations. Lawmakers proceed from the need of strict regulation and to determine the circle of persons who are granted the right to make donations. The fact is that donors are often not driven with altruistic motives, but with the desire to influence the current activities of parties and the decisions that they make. Anonymous donation is generally prohibited. Taking into account the

\footnotetext{
${ }^{6}$ Recommendations 1516 (2001). Parliamentary Assembly from www.assembly.coe.int
} 
peculiarities of the legal status of parties, they are obliged to disclose information about donors, what is consistent with the principle of transparency of political parties. It is also prohibited to transfer donations to foreign states, legal entities and individuals, international organizations, state (municipal) authorities, religious organizations, legal entities with a significant share of state participation and others. In some countries, it is also prohibited to act as a party donor for legal entities in general (France).

The scope of donations is also limited. For Russia, Spain, Cyprus, Germany and other countries such restrictions are typical. But in Britain, for example, the prevailing approach is that such restrictions do not contribute to the development of democracy and political competition.

It is interesting to consider the possibility of providing sponsorship to a political party. Sponsorship can be used to bypass prohibitions and restrictions of donations. Analysis of the legislation of European countries showed the existence of three approaches to the legal regulation of sponsorship. According to the first (Russia, Belgium, partly Germany), the law does not mention this institution. The second approach is based on a total ban on sponsorship of political parties. For example, the Organic Law "On the Financing of Political Parties" adopted in 2007 provides for the prohibition of payment for goods, works and services by third parties in the interests of a political party ${ }^{7}$. Another example is Serbian legislation on the financing of political parties, prohibiting "indirect" donation $^{8}$. The third approach is typical for the UK, where sponsorship is equivalent to donations and is assistance aimed at reimbursing the costs of organizing and / or holding meetings, conferences, seminars and other events; production and distribution of printed materials in the interests of political parties; conducting research on behalf of the party ${ }^{9}$.

In our opinion, in the interests of countering political corruption, the most reasonable is the latter approach, which allows parties to attract the necessary resources to carry out a political struggle. At the same time, revenues from this source should be open and subject to control by both the state and society.

It is worth noting that, thanks to the research of legislation in various fields in order to identify corruption risks, conducted by GRECO, recommendations to improve the legal regulation, including party funding, were made. Almost all of these recommendations are reflected in legal acts. The transparency principle was named as one of the most effective tools to combat political corruption. The implementation of this principle, for example, consists of fixing the obligation of parties to keep financial accounting, as well as publish reports for the general public. Such reports reflect the size of the attracted funds, indicating the sources, the composition of the property, the amount and purpose of spending the funds, and other data.

In this case, we can talk about the presence of some control by civil society. According to the existing international recommendations in the field of ensuring the transparency of financing political parties, the financial report must meet four fundamental criteria:

1) Periodicity. Financial reports of political parties should be submitted to authorized bodies at regular intervals, which should be reasonably short. In accordance with Art. 13 Recommendations REC 2003 (04) financial reporting documents should be provided for auditing "at least once a year" ${ }^{\text {, }}$. The laws of many countries comply with these recommendations. For example, according to French law, reports of political parties are compiled annually and must be submitted to the authorized bodies within the six months following the reporting period ${ }^{11}$.

2) Openness to the general public ${ }^{12}$ (Access to Information about Political Finance, from www.aceproject.org). Access to information about the sources of party funding and its volume makes it possible to study and analyze them by society and civil society institutions. Along with this, it is worth noting that in many European countries, financial reports of parties are subject to the control and supervision by independent authorities. However, the

\footnotetext{
${ }^{7}$ Ley Organica 8/2007, de 4 de Julio, sobre financioción de los partidos políticos. Publicado en BOE núm. 160 de 05 de Julio de 2007 (Organic Law 8/2007, of July 4, on the financing of political parties)

${ }^{8}$ Zakon o finansiranju politićnih aktivnosti Republike Srbije 2011//Službeni Glasnik Republike Srbije from //www. acas.rs (Law on Financing Political Activities of the Republic of Serbia 2011)

9 Political Parties, Elections and Referendums Act 2000 (amended by Political Parties and Elections Act 2009) from //www.legislation.gov.uk

${ }^{10}$ Recommendation No. Rec (2003) 4 of the Committee of Ministers of the Council of Europe "On common rules against corruption in the funding of political parties and electoral campaigns". From 04/08/2003 at the 835th meeting of ministerial representatives //Journalofficieldel'Unioneuropéenne L 297 du 15.11.2003

${ }^{11}$ Maklakova, V.V., Alferova, E.V. (2010). Finansirovanie politicheskih partij vo Francii. Pravovoe regulirovanie: sbornik perevodov (Funding of political parties in France. Legal regulation: a collection of translations). RAS. INION. Center of social scientific-inform. research. Moscow.

${ }^{12}$ Access to Information about Political Finance, from www.aceproject.org
} 
degree of independence of such bodies varies ${ }^{13}$. Moreover, it is obvious that the legislation of most European countries, as repeatedly stated in the GRECO reports, does not contain sufficient legal regulation for exercising control over the financing of political parties by an independent body ${ }^{14}$.

In some states, along with the audit of financial statements, there is also a mandatory audit of the activities of parties, in particular, in Cyprus and Russia. As a rule, a compulsory audit is conducted in relation to the financial statements of those parties that have the right to receive state funding. For example, in Cyprus, a similar control is carried out in respect of all political parties, which is quite reasonable, because all parties have the right to state funding. In Russia, only parties that overcome the 3\% barrier of votes based on the results of the election of deputies to the State Duma and the President of Russia have the right to receive state subsidies. Today there are only four parties represented in the legislative branch of power. At the same time, the obligation to conduct an audit is provided if the party was able to attract more than 60 million rubles in donations for the year. Despite of the positive aspects of the introduction of the mandatory audit requirement, the requirement to disclose the audit report to the company is not provided. We believe that such report is provided by the parties to the authorized party funding control body. We assume that it is necessary to publish an audit report for the interests of developing transparency in the activities of parties.

3) Completeness and detail. The data displayed in the statements should reflect the sources and volumes of income and / or expenses, the composition of the property and the obligations of the parties. Disclosure of party donor data is equally important. In a number of states, reporting includes data on persons who have provided loans / credits for parties, as well as the terms of such agreements. Exactly loans are often used to circumvent the legislative limitation of the volume of donations, as well as the circle of persons who are granted the right to act as donors. It is worth emphasizing that reporting is provided not only by the party itself, but also by its regional offices to the territorial office of the authorized body.

4) The financial report should be understandable ${ }^{15}$. In this case, we are faced with a rather evaluative concept "understandable". We believe that we can proceed from the rule of the "average person", i.e. a person with average abilities, having an average level of knowledge and education, i.e. not a specialist in finance, accounting, etc. The reporting form is different in different states, however, as a rule, it is a tabular form, which facilitates the perception of information.

An important guarantor of the implementation of legislation in the field of party funding is the possibility of bringing political parties and its officials to justice. We are talking about administrative liability, for example, for violation of the deadlines for the submission of a financial report to the authorized body, violation of the mandatory audit deadlines, use of funds in violation of the procedure for submitting them, and their unlawful provision. Although in this case sometimes we encounter the parties 'constitutional legal responsibility: regular non-provision of financial reports, for example in Russia, it is the basis for suspending the activities of the party, and in case of repeated violation - its liquidation.

Thus, it can be stated that today the legal regulation of the financing of political parties is extremely important for countering corruption. After all, the involvement of parties in corrupt relations in many countries led to a crisis of their legitimacy. According to a study conducted in $2013^{16}$ in 55 out of 107 countries political parties are named as the most corrupt institutions.

\subsection{Favoritism}

Favoritism can be called another type of manifestation of political corruption. It means a deliberately hypertrophied assessment of the positive qualities of a person, what leads to unreasonable and / or unlawful advancement of his interests to the detriment of the interests of public service and public interests. From this definition, we can distinguish features of favoritism: guilt (the person choosing his "favorite" knows for sure about the wrongful act), the wrongful goal (promotion of the person in the service is not of the interests of the service, but it's personal, self-serving or other motives, with "exaggerated" assessment of the qualities and qualifications of the candidate) negative consequences (they may be different, for example, reduced motivation

\footnotetext{
${ }^{13}$ Biezen, Ingrid van, (2003) Financing political parties and election campaigns-guidelines. University of Birmingham. Council of Europe Publishing. Strasbourg. pp. 51-53.

${ }^{14}$ Fighting Corruption. Political Funding by Mr. Yves-Marie Doublet. Thematic Review of GRECO's Third Evaluation Round. from www.coe.int

${ }^{15}$ Biezen, Ingrid van, (2003) Financing political parties and election campaigns-guidelines. University of Birmingham. Council of Europe Publishing. Strasbourg

${ }^{16}$ Transparency International, 2013. Global Corrupt Barometer from https://transparency.org.ru/research/barometr-mirovoy-korruptsii/
} 
of employees, reduced quality of duty due to the fact that the person holding the position does not meet the requirements, lack of initiative, etc.). Favoritism is a fairly broad concept. If we try to analyze what lies at the basis of the "hyper-assessment", the reasons why not the "most worthy" person got promotion or appointment, then certain types of favoritism can be identified. The reasons why a person can become a "favorite" form the classification of the types of favoritism:

1) Nepotism, as the most common, and perhaps the most obvious manifestation of favoritism, is considered to be the provision of certain advantages, when a public servant takes a certain position, based on kinship ties. The legislation of many states prohibits the employment of posts, which will lead to the direct subordination of one person to another. However, this restriction applies only to posts that are strictly subordinate. As for posts that are not formally interrelated, there is no obvious (open) nepotism here, just as the opposite cannot be said with confidence.

2) The provision of certain benefits to person, depending on the community of their places of birth, places of residence.

3) The provision of certain benefits to person, depending on his belonging to a certain nationality, religion, ideology, etc.

We emphasize once again that favoritism is a provision of benefits to persons, who obviously do not meet the requirements for a candidate for a particular position. Promotion of someone in the service is not favoritism. Complying with the law, one can hardly talk about favoritism, but rather about some sympathy, which is due to human nature.

The danger of favoritism is expressed in the fact that it leads to inefficient personnel decisions (appointment of a person who does not meet the requirements), it can lead to an outflow of promising employees and lack of initiative of employees, who do not see growth prospects. Another problem is the irresponsibility of the favorites, who enjoy a certain "patronage"17.

As the most effective methods of countering this form of political corruption, we again see openness, transparency of the electoral process, as well as the presence of qualification requirements for candidates for a particular civil service position. Today, the competitive basis of occupying a position is widely used, the creation of competitive commissions, whose task is to make decisions collectively.

\subsection{Corruption Offenses in the State Civil Service}

Another type of political corruption is corruption in the civil service. This group of corrupt practices is extremely extensive. The laws of the states have their own characteristics, therefore it is not possible to disclose all possible corpus delicti of offenses in this work.

Speaking of this form of political corruption, we primarily mean "the use by a person in a public office, entrusted to him of state authority and rights, official position and status in the state power system, the status of a public authority that he represents in order to illegal gain of personal and (or) group, including in favor of third parties, political benefit (political enrichment)",18.

Speaking about the fight against this type of corruption, it is necessary to point out such a way to control the activities of civil servants as providing them with information about expenditures and incomes, as well as with respect to existing property ${ }^{19}$. The international organization of the Group of States against Corruption (GRECO), conducting research of the legislation of states on the subject of corruption risks, has repeatedly stressed the importance of including such a requirement in national regulatory legal acts.

Today, such a rule is present in almost all European countries, and similar requirements have been introduced in Russia. Such reports are provided for the calendar year by persons occupying certain positions in the system of state (in a number of countries - municipal) services, and also provide information on income and expenses in respect of spouses and minor children. Such a system is also not a panacea and has been repeatedly criticized. However, in this case we have the opportunity to conduct some kind of public control.

\footnotetext{
${ }^{17}$ Safina, D.M., (2013). Vliianie favoritizma i nepotizma na organizacionnoe i ekonomicheskoe razvitie (The influence of favoritism and nepotism on organizational and economic development). Diskussiia. Number 10 (40). pp. 89-94

${ }^{18}$ Nisnevich, Yu.A., (2012). Politicheskaia korrupiia: opredeleniie, formy proiavleniia, mehanizm i resursy (Political corruption: definition, forms of manifestation, mechanism and resources). Tehnologizaciia politicheskih processov v usloviiah globalizacii: teoriia, opyt, perspektivy. Moscow, Federaciia mira i soglasiia, pp. 193-201

${ }^{19}$ Vorontsov, S. A., Mamychev, A. Yu., Ponedelkov, A. V., Medvedev, V. G., Magomedkhanov, R. G., (2018) Fighting against corruption in modern Russia: problems and prospects . Amazonia Investiga. Vol. 7 Núm. 14/ (Septiembre-Octubre). pp. 322-331
} 
It is worth noting that for violation of the requirements of the legislation on the timing and procedure for providing information about the incomes of a public servant and his family members, as a rule, measures of legal liability are provided (most often administrative and disciplinary). In this case, the presumption of guilt, i.e. the provision of false information is considered as an intentional act.

\section{Concluding Remarks}

In conclusion, we note that it is difficult to counteract corruption, including political, only with legal means. Experience shows that it is impossible to achieve the desired result only through an effective legal framework, granting broad powers to law enforcement agencies, while the socio-economic conditions contributing corruption and its prosperity are not eliminated. Predominantly punitive forms of fighting corruption do not lead to success.

Attempts to create systemic barriers to the spread of corruption have a long history. However, no Western or Eastern state has really defeated corruption by the moment. The most effective measure of countering corruption is to prevent it. Preventive means of state and non-state institutions are still a priority to all other measures to countering corruption. In modern period, states, guided by the recommendations presented in international regulatory legal acts, created national legal framework for countering corruption. But an important issue is the implementation of the entire system of anti-corruption measures (legal, economic, social, political), as well as the quality of their implementation. This is evidenced by the rating of states in the countering corruption ${ }^{20}$. The corruption index in different countries shows not only the scope of corruption, but to a greater extent indicates the effectiveness of states struggling against corruption in the domestic space.

\section{Copyrights}

Copyright for this article is retained by the author(s), with first publication rights granted to the journal.

This is an open-access article distributed under the terms and conditions of the Creative Commons Attribution license (http://creativecommons.org/licenses/by/4.0/).

${ }^{20}$ Corruption Perceptions Index 2017 from https://www.transparency.org/news/feature/corruption_perceptions_index_2017 